\title{
Macroeconomic Influence on the Nepalese Stock Market
}

\author{
Mukti Bahadur Khatri ${ }^{*}$
}

\begin{abstract}
This study examines the dynamic relationship among the stock market and macroeconomic factors such as nominal domestic variables (inflation, money supply, and interest rate), real economic activity (gross domestic product) and foreign variable (exchange rate and foreign direct investment) of Nepal. It has used Johansen and Juselius (1990) method of multivariate cointegration for the period Mid-July 1994 to Mid-July 2015. The finding of this study shows that the stock prices are positively and significantly related to money supply. Real economic activity and interest rate have insignificant and negative relationship with the stock prices. Similarly, foreign direct investment, inflation (CPI) and exchange rate with US dollar have a positive and insignificant relationship with the Nepalese stock market. Accordingly, the VEC estimates suggest that there is no significant effect of macroeconomic variables to the Nepalese stock price in the short run. In general, the presence of cointegration and causality suggest that Nepalese stock market is not efficient in both the short run and the long run.
\end{abstract}

Key Words: Stock Market, Macroeconomic Variables, Cointegration, VEC Estimates, Causality Test

JEL Classification: G10, E44, C32

\footnotetext{
Mr. Khatri is a Lecturer of Economics at Trichandra Multiple Campus, Ghantaghar, TU, Nepal. This article is based on the author's Faculty Research Report titled "Macroeconomic Influence on the Nepalese Stock Market" supported by University Grants Commission, Sanothimi, Bhaktapur.
} 


\section{INTRODUCTION}

The history of Nepalese stock market begins with Biratnagar Jute Mills and Nepal Bank Limited who floated their shares in 1937 AD, even though Nepalese stock market institutionalized only after the establishment of Securities Market Centre in 1976. Later on, it was changed into Securities Exchange Center (SEC) in 1984 AD. Further, the modernization begin in 1992 under the Enhanced Structural Adjustment Program (ESAP) converted SEC into Nepal Stock Exchange (NEPSE) with the sole objective of carrying out secondary market services for stocks. On January 13, 1994, NEPSE opened a trading floor introducing an 'open outcry system' which was replaced by 'automated trading system' beginning August 24, 2007.

NEPSE is the only organized stock exchange (secondary market) in Nepal operating under Securities Act, 2006. It turned itself into a profit seeking organization in May 2008 from its initial not for profit organization. The recent developments in NEPSE includes provision of real time information (live trading activity) to investors from November 2, 2008 and introduction of the over-thecounter (OTC) market from June 4, 2008 which provides the market for trading of shares that are de-listed and that are not listed in NEPSE for failing to meet the listing criteria. The historical performance of the NEPSE for the period of MidJuly 1994 to Mid- July 2015, number of companies listed and number (paid up value) of listed securities both have increased from 66 in 1994 to 232 in 2015. In the same time market capitalization ratio (ratio of market capitalization on nominal GDP at market price) is also (in million) increased from 13872 to 989404 million (NRB, 2017).

There are various empirical research that examines the influence of macroeconomic factors on the stock market. These studies are based on the asset valuation model which argues that macroeconomic factors can affect stock price in two distinct ways. Firstly, they can change expected cash flows of the firm and by this means change firm's stock price. Secondly, they can change the discount rate or required rate of return used by the market participants (Crowder, 2006). For this purpose nominal domestic variables (inflation, money supply, interest rate), real domestic activity (gross domestic product, unemployment rate) and foreign variables (exchange rate, oil price and international stock exchange index) reflecting the real, monetary and financial sectors of an economy.

The existence of macroeconomic influence on the stock market suggests that stock price can be predicted using the publicly available information on macroeconomic variables. The occurrence of which contradicts with Fama's (1970) Efficient Market Hypothesis (EMH). According to him "A capital market is efficient if all the information in some information set $\phi_{t}$ is "fully reflected" in 
security prices" Fama distinguished three versions of the efficient markets based on this set of information $\phi_{t}$ reflected $^{1}$ in security prices:

(i) The Weak Form of the Efficient Market Hypothesis: It refers to the information based on historical series of prices, which is just the past price (or returns).

(ii) The Semi-Strong Form of the Efficient Market Hypothesis: It refers to the publicly available information based on speed of price adjustment to other obviously available information such as statement of stock openings, new security issues, annual reports etc.

(iii) The Strong Form of the Efficient Market Hypothesis: It refers to private information based on all information of market participants or any investor or groups (e.g., management of mutual funds) have monopolistic access to any information relevant for the formations of prices have just appeared.

On the basis of above discussion, this study analyzes relationships between a group of macroeconomic variables and the Nepalese stock market index. The objective of this study is to investigate whether stock prices may serve as a leading indicator for macroeconomic variables in Nepalese economy or a group of macroeconomic variables may serve as a leading indicator for stock returns in Nepal. Granger causality tests have been employed to estimate the relationships on the basis of data from 1994 to 2015 (i.e. 22 years).

\section{REVIEW OF LITERATURE}

The stock market has been historically analyzed as a reliable tool to indicate economic progress. The theoretical approach to studying the relationship between the macroeconomic factors and stock market is provided by the financial theory, the so called present value model which is used to describe the valuation of assets. The model suggests that the stock price is equal to the present discounted value of the future expected cash flows (Humpe and Macmillan, 2007). This is expressed as

$$
P_{t}=\sum_{j=1}^{k} E_{t}\left(\frac{C F_{t+j}}{\left(1+R_{t}\right)^{j}}\right)
$$

\footnotetext{
1 The set of information $\emptyset_{\mathrm{t}}$ reflected in security prices at $\mathrm{t}$ time period distinguished three versions of the efficient markets (Fama, 1970). This classification has been widely adopted in the literature on financial markets for convenience.
} 
Where,

$P_{t}$ is the current asset (stock) price or intrinsic value of asset (stock)

$E_{t}$ is the conditional expectations operator based on the information available to market participants at time $\mathrm{t}$

$C F_{t}$ is the cash flows at time $\mathrm{t}$

$R_{t}$ is the discount rate or rate of return used by the market participants to discount future values

$k$ is the investor's time horizon or holding period

From equation (1), it can be seen that macroeconomic factors can affect stock price in two distinct ways. First, they can alter expected cash flows of the firm and thereby alter firm's stock price. Second, they can alter the discount rate or required rate of return used by the market participants. ${ }^{2}$ The asset pricing theory (such as Arbitrage Pricing Theory) is silent about which macroeconomic variables are likely to influence all assets (Chen, Roll and Ross, 1986). The study hypothesizes these factors to be comprising of nominal domestic variables (inflation, money supply and interest rate), real domestic activity (real economic activity) and foreign variables (such as exchange rate between US dollars and Nepalese Rupees, FDI) have influence on Nepalese stock market.

Shrestha and Subedi (2014) examined the determinants of stock market performance in Nepal and based on stock market index of monthly data of 2000 to 2014, and using OLS estimations of behavioral equations. According to their study, there is strong positive relationship with inflation and growth of money supply along with negative response to interest rate.

Joshi (2009) examined the dynamic relationship among the stock market and macroeconomic factors represented by nominal domestic variables (inflation, money supply and interest rate), real economic activity (gross domestic product) and foreign variable (exchange rate) for a stock market of Nepal. This study has also used Johansen and Juselius (1990) method of multivariate cointegration for the period Mid-July 1995 to Mid-June 2006. This study has acknowledged dynamic relationship among stock index and macroeconomic variables. Similarly the presence of cointegration and causality of the study suggests that Nepalese stock market is not efficient in the short run and also in the long run.

Pilinkus (2009) examined the relationships between a group of macroeconomic variables and the Lithuanian stock market index, i.e. OMX Vilnius index. The

2 Required rate of return consists of nominal risk free rate and risk premium (for inflation, default, maturity). Nominal risk free rate in turn compromises of real risk free rate and inflation premium for expected inflation. 
study revealed a group of macroeconomic variables may offer as a leading indicator for stock returns in Lithuania. Granger causality tests have been employed to estimate the relationship on the basis of data from December 1999 to March 2008. The research signifies that some macroeconomic variables (e.g., GDP deflator, net export, FDI etc.) guide Lithuanian stock market returns, some macroeconomic variables (e.g., GDP, material investment, construction volume index, etc.) are led by the OMXV index and, finally, some macroeconomic indices (e.g., money supply, BOP, etc.) and the stock market returns Granger cause each other.

Humpe and Macmillan (2007) examined under the framework of a standard discounted value model whether a number of macroeconomic variables influence stock prices in the USA and Japan. A cointegration analysis is used in order to model the long term relationship between macroeconomic variables such as industrial production, the consumer price index, money supply, long term interest rates and stock prices in Japan and the USA. This study found the data are consistent with a single cointegrating vector for the USA, where stock prices are positively related to industrial production and inversely associated to both the CPI and a long term interest rate. It also finds an insignificant (although positive) relationship between stock prices of USA and the money supply. However, for the Japanese data it finds two cointegrating vectors i.e. stock prices $\&$ industrial production. Where, stock price are positively subjective by industrial production and negatively by the money supply along with the industrial production is negatively subjective by the CPI and a long term interest rate. These contrasting results may be due to the fall in the Japanese economy during the 1990s and consequent liquidity trap.

Gay (2008) argues that the relationship between share prices and macroeconomic variables is well acknowledged for the United States and other major economies, however, what is the relationship between share prices and economic activity in emerging economies, is less researched. The goal of this study was to investigate the time series relationship between stock market index prices and the macroeconomic variables such as exchange rate and oil price for Brazil, Russia, India, and China (BRIC) using the Box-Jenkins ARIMA model. Although no significant relationship was found between particular exchange rate and oil price on the stock market index prices of either BRIC country due to other domestic and international macroeconomic factors on stock market returns, deserving further research. This study also found no significant relationship between present and past stock market returns, signifying the markets of Brazil, Russia, India, and China show evidence of the weak-form of market efficiency.

Tursoy, Nil and Husam (2008) empirically tested the Arbitrage Pricing Theory (APT) in Istanbul Stock Exchange (ISE) for the period of February 2001 up to 
September 2005 on a monthly base. In this paper, various macroeconomic variables representing the basic indicator of an economy employed money supply (M2), industrial production, crude oil price, consumer price index (CPI), export, import, price of gold, interest rate, exchange rate, GDP, unemployment rate, foreign reserve and market pressure index (MPI). This study tested 13 macroeconomic variables against 11 industry portfolios of Istanbul Stock Exchange to examine the effects of those variables on stocks' returns. Using ordinary least square (OLS) technique and it observed that there are some differences among the industry sector portfolios.

Gan \& et al. (2006) examined the relationships between a set of seven macroeconomic variables and the New Zealand Stock Index from January 1990 to January 2003 using cointegration tests. Particularly, this study employed the Johansen Maximum Likelihood and Granger-causality tests to find out results. In addition, this study examines the short run dynamic linkages between NZSE40 and macroeconomic variables by using innovation accounting analyses. Finally, this study found the NZSE40 is consistently influenced by the money supply, interest rate and real GDP. There is no evidence that the New Zealand Stock Index is a leading indicator due to change in macroeconomic variables.

Arnold \& Vrugt (2006) examine empirical evidence on the link between stock market volatility and macroeconomic uncertainty. The findings that US stock market volatility is significantly related to the dispersion in economic forecasts from survey of professional forecaster (SPF) survey participants over the period from 1969 to 1996 . This link between stock market volatility and macroeconomic uncertainty is much stronger than that between stock market volatility and the time-series measures of macroeconomic volatility, but disappears after 1996.

The seminal work in this aspect is that of Chen, Roll and Ross (1986) for US. They examine a range of business conditions variable that might be related to stock returns because they are related to shocks to expected future cash flows or discount rates. They show that the variables, such as the growth rate of industrial production, inflation (expected and unexpected), the spread between long and short interest rates (Term Structure Spread), and the spread between high and lowgrade bonds a bond (Default Risk Premium), systematically affect stock returns. More specifically, they conclude that the default and term premia are priced risk factors that Industrial Production is a strong candidate for being a risk factor, and that weaker evidence supports Inflation's claim to that status (Flannery and Protopapadakis, 2002). Followed by this, many empirical studies have emerged focusing mostly on developed markets; for instance, Lee (1992), Darrat and Dickens (1999), Park and Rati (2000), Laopodis (2006), Patra and Poshakwale (2006), Ratanapakorn and Sharma (2007) among others and few on emerging 
equity markets $^{3}$ (e.g., Mookerjee and Yu, 1997; Lee, 1997; Tsoukalas, 2003; AlKhazali, 2003; Gunasekarge, Pisedtalasai and Power, 2004; Wickremasinghe, 2006), all of which documented relationship between stock market and at least one of the macroeconomic variables.

\section{CONCEPTUAL FRAMEWORK}

This study primarily focuses on stock prices. Six non-equity macroeconomic variables such as inflation, money supply, interest rate, real economic activity, exchange rate and foreign direct investment are used in an attempt to examine the relationship between these variables and stock prices. The relationship between stock prices and macroeconomic factors is based on the two theoretical modelsthe Efficient Markets Hypothesis (Fama, 1970) and the present value model (Humpe and Macmillan, 2007 and Allen et al., 2004).

It is widely accepted that increase in future levels of real economic activity, as measured by GDP will affect the future cash flows in the same direction. Stock returns being a function of future cash flows, there is positive relationship with the real economic activity.

\section{Conceptual Framework}

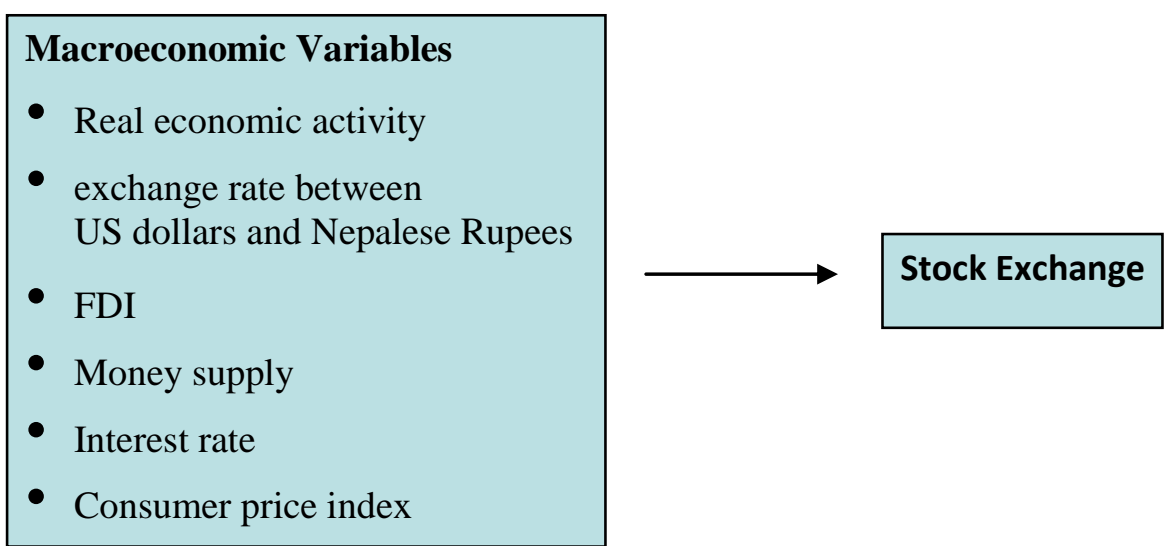

3 According to the International Finance Corporation, a unit of the World Bank, an emerging equity market is an equity market from a developing country. A developing country is one that has a low income (US\$ 783 or less per capita in 1997) or middle income (US\$ 783 to 9656 per capita in 1997). 
Therefore, this relationship can be explained as the following model:

LNEPSE $=\mathrm{f}($ LGDP, LEXR, LFDI, LM1, LTBR, LCPI)

In equation form this can be written as:

$$
\mathrm{LNEPSE}=\beta 0+\beta 1 \mathrm{LGDP}+\beta 2 \mathrm{LXER}+\beta 3 \mathrm{LFDI}+\beta 4 \mathrm{LM} 1+\beta 5 \mathrm{LBTR}+\beta 6 \mathrm{LCPI}
$$

Where, variables LNEPSE, LGDP, LEXR, LFDI, LM1, LTBR and LCPI denote log values of Nepal stock exchange index, real gross domestic product, NRs/US dollar exchange rate, foreign direct investment, narrow money supply, 91-days Treasury bill rate, and consumer price index. The expected signs of the coefficients of the variables are:

$$
\beta 1>0, \beta 3>0, \beta 5<0 \text { and others are determined empirically. }
$$

\section{DATA AND ANALYSIS}

\subsection{Nature of Data}

The time series data of secondary nature compromising of stock prices and six non-equity macroeconomic variables such as inflation, money supply, interest rate (weight average treasury bills rate -TBR), real economic activity, FDI and exchange rate has been used for the study. In this study annual data for the period 1994 to 2015 on the Nepal Stock Exchange (NEPSE) index and the macroeconomic variables were obtained from Annual Report of Nepal Stock Exchange and Quarterly Economic Bulletin of Nepal Rastra Bank. The NEPSE index is a broad based value weighted index and is available from July 1994. The choice of the macroeconomic variables is based on the prior empirical findings in the developed and emerging stock markets and their relevance and importance to the Nepalese economy.

\subsection{Description of Stock Price and Macroeconomic Variables}

Concerned macroeconomic variables are defined as follows: 
Table 1: Description of Variables

\begin{tabular}{|l|l|l|}
\hline Symbol & Variable & Definitions \\
\hline LNEPSE & Stock Prices & Natural log of NEPSE Stock Prices Index \\
\hline LM1 & Money supply & Natural log of Narrow Money Supply \\
\hline LCPI & Inflation & Natural log of National Consumer Price Index \\
\hline LTBR & Interest Rate & $\begin{array}{l}\text { Natural log of weighted average 91-days } \\
\text { Treasury Bills Rate }\end{array}$ \\
\hline LGDP & Real Economic Activity & Natural log of Real Gross Domestic Product \\
\hline LFDI & Foreign Direct Investment & Natural log of Foreign Direct Investment \\
\hline LEXR & Exchange Rate & Natural log of NRs/US Dollar Exchange Rate \\
\hline
\end{tabular}

Here, the first differences of variables are indicated by $\Delta$ which represents change rates or instance, $\triangle$ LNEPSE indicates growth of NEPSE stock price index which is also called as stock returns. Accordingly other variables are also defined.

\subsection{Summary Statistics}

It represents summary report of Mean, Standard Deviation, Maximum, Minimum, Skewness, and Kurtosis, which explain synopsis about the distribution, variability, and central tendency of a variable.

\section{Table 2: Summary Statistics}

\begin{tabular}{|l|l|l|l|l|l|l|l|l|}
\hline Variables & $\begin{array}{l}\text { No. of } \\
\text { Obs. }\end{array}$ & Mean & Min. & Max. & $\begin{array}{l}\text { Std. } \\
\text { Dev. }\end{array}$ & Skew & Kurt & $\begin{array}{l}\text { Jarque- } \\
\text { Bera Test }\end{array}$ \\
\hline$\Delta$ LNEPSE & 22 & 0.03 & -0.45 & 0.57 & 0.31 & 0.19 & -0.93 & 0.73 \\
\hline$\Delta$ LGDP & 22 & 0.04 & 0.001 & 0.08 & 0.02 & 0.39 & 0.43 & 0.57 \\
\hline$\Delta$ LEXR & 22 & 0.02 & -0.08 & 0.17 & 0.07 & 0.33 & -0.72 & 0.69 \\
\hline$\Delta$ LFDI & 22 & 0.02 & -2.64 & 1.54 & 0.94 & -1.06 & 2.23 & $6.70^{* *}$ \\
\hline$\Delta$ LM1 & 22 & 0.12 & 0.04 & 0.24 & 0.05 & 0.55 & -0.09 & 0.88 \\
\hline$\Delta$ LTBR & 22 & -0.10 & -1.73 & 0.69 & 0.58 & -1.38 & 1.99 & $8.28^{* * *}$ \\
\hline$\Delta$ LCPI & 22 & 0.07 & 0.02 & 0.12 & 0.03 & 0.03 & -1.09 & 0.85 \\
\hline
\end{tabular}

Note: This table displays the summary statistics of concerned variables for the sample period MidJuly 1994 to Mid-July 2015. The concerned variables $\triangle$ LNEPSE, $\triangle$ LCPI, $\triangle$ LM1 and $\Delta$ LTBR, $\triangle \mathrm{LGDP}, \triangle \mathrm{LFDI}$ and $\triangle \mathrm{LEXR}$ denote first difference of log values of Nepal Stock Exchange index, consumer price index, narrow money supply, 91-days Treasury Bill Rate, real gross domestic product, foreign direct investment and NRs/US dollar exchange rate.

***Significant at the 1-percent level,

**Significant at the 5-percent level

For the $\triangle$ LNEPSE the mean is 0.03 and the standard deviation is 0.31 . The largest and lowest value for this is -0.45 and 0.57 . The variable shows positive skewness indicating the higher probability of very large positive stock prices. Similarly the kurtosis shows that it is platykurtic (fat or short tailed) with lower than normal kurtosis (that is $\mathrm{K}>3$ ), which means that there is a higher probability than usual 
for extreme values (very good or very bad returns) to occur. The combination of these presents the normal distribution of the variable as indicated by the JB test of normality, where $\mathrm{p}$ value of JB test is reasonably high.

For the macroeconomic variables, the mean is the highest for LM1 and the lowest for LTBR. The figures in the standard deviation column indicate that LFDI is highly volatile while LGDP is less volatile.

\subsection{Correlation Matrix}

Table 3 shows that there is moderate correlation between the $\triangle$ LNEPSE and most of the macroeconomic variables. However, the macroeconomic variables except $\Delta$ LGDP, $\triangle \mathrm{LEXR}$ and $\triangle \mathrm{LCPI}$ demonstrate strong correlation with each other.

\section{Table 3: Correlation Matrix}

\begin{tabular}{|l|l|l|l|l|l|l|l|}
\hline $\begin{array}{c}\text { Correlation } \\
\text { Matrix }\end{array}$ & $\Delta$ LNEPSE & $\Delta$ LGDP & $\Delta$ LEXR & $\Delta$ LFDI & $\Delta$ LM1 & $\Delta$ LTBR & $\Delta$ LCPI \\
\hline$\Delta$ LNEPSE & 1.0000 & & & & & & \\
\hline$\Delta$ LGDP & -0.1270 & 1.0000 & & & & & \\
\hline$\Delta$ LEXR & -0.0314 & 0.1822 & 1.0000 & & & & \\
\hline$\Delta$ LFDI & 0.2700 & 0.2969 & -0.3780 & 1.0000 & & & \\
\hline$\Delta$ LM1 & 0.1921 & 0.0175 & 0.1187 & 0.2742 & 1.0000 & & \\
\hline$\Delta$ LTBR & 0.4385 & 0.0486 & -0.3315 & 0.7025 & 0.5123 & 1.0000 & \\
\hline$\Delta$ LCPI & -0.2466 & 0.5228 & 0.4345 & -0.1558 & 0.1391 & -0.2009 & 1.0000 \\
\hline NOt: Th
\end{tabular}

Note: This table displays the correlation of concerned variables for the sample period Mid-July 1994 to Mid-July 2015. The concerned variables $\triangle \mathrm{LNEPSE}, \Delta \mathrm{LCPI}, \Delta \mathrm{LM} 1$ and $\triangle \mathrm{LTBR}, \Delta \mathrm{LGDP}$, $\triangle$ LFDI and $\triangle$ LEXR denote first difference of log values of Nepal Stock Exchange index, consumer price index, narrow money supply, 91-days Treasury Bill Rate, real gross domestic product, foreign direct investment and NRs/US dollar exchange rate.

\subsection{Cointegration}

A linear combination of log of Nepal Stock Exchange (LNEPSE) index, consumer price index (LCPI), narrow money supply (LM1), three months Treasury bill rate (LTBR), nominal gross domestic product (LGDP), US dollar exchange rate (LEXR), and foreign direct investment (LFDI) time series can be stationary despite being individually non-stationary. The cointegration of two (or more) time series implies that there is a long-run, or equilibrium, relationship between them. So it was employed to examine the dynamic relationship between NEPSE and macroeconomic variables. The following steps were followed in this regard: 


\subsubsection{Unit Root Test}

Before testing for the relationship between the seven variables in the system of equations, unit root test is carried out for each variable. Table 4 displays the results of the Augmented Dickey-Fuller (ADF, 1981) test for unit roots. The results suggest that all the variables are non stationary in their levels. These results are consistent when an intercept and linear trend are included as deterministic components in the test equations.

Let us observe the ADF test of level and first difference of Nepalese stock market index and macroeconomic variables (time series). According to ADF results of first difference, absolute calculated value of ' $\mathrm{T}$ ' is more than absolute value of $\mathrm{T}$ at $1 \%, 5 \%$ and $10 \%$. So, the null Hypothesis is rejected at $1 \%, 5 \%$ and $10 \%$. It implies that there is no Unit Root problem. Therefore, there is no Unit Root (i.e. stationary). On the contrary, ADF results of level shows an Unit Root Problems. They are given detail as follows.

Table 4: Augmented Dickey-Fuller Test for Unit Root Test

\begin{tabular}{|l|l|l|l|l|l|l|}
\hline \multirow{2}{*}{ Variables } & \multicolumn{3}{|c|}{ For Level } & \multicolumn{3}{c|}{ For First Difference } \\
\cline { 2 - 7 } & $\begin{array}{c}\text { Estimated } \\
\text { Value }\end{array}$ & $\begin{array}{c}\text { Test } \\
\text { Statistic: } \\
\text { tau }\end{array}$ & P-Value & $\begin{array}{c}\text { Estimated } \\
\text { Value }\end{array}$ & $\begin{array}{c}\text { Test } \\
\text { Statistic: } \\
\text { tau }\end{array}$ & P-Value \\
\hline LNEPSE & -0.164437 & -1.19011 & 0.6531 & -0.460616 & -1.98222 & 0.2906 \\
\hline LGDP & -0.0438757 & -1.92266 & 0.3149 & -0.76179 & -3.25899 & 0.03508 \\
\hline LEXR & -0.291533 & -2.57604 & 0.1168 & -1.1273 & -4.17686 & 0.00613 \\
\hline LFDI & -0.731407 & -3.14514 & 0.04207 & -1.35212 & -3.91872 & 0.01003 \\
\hline LM1 & 0.000179651 & 0.00834831 & 0.947 & -0.764153 & -2.7207 & 0.09222 \\
\hline LTBR & -0.553044 & -2.04721 & 0.266 & -0.921956 & -2.45061 & 0.1448 \\
\hline LCPI & 0.0251975 & 1.07566 & 0.9953 & -0.471456 & -2.02287 & 0.275 \\
\hline
\end{tabular}

Note: This table displays ADF test for the unit roots for the sample period Mid-July 1994 to MidJuly 2015 Significant at the 5-percent level. The variables LNEPSE, LCPI, LM1 and LTBR, LGDP, LFDI and LEXR denote log values of Nepal Stock Exchange index, consumer price index, narrow money supply, 91-days Treasury Bill Rate, real gross domestic product, foreign direct investment and NRs/US dollar exchange rate.

\subsubsection{Vector Autoregression (VAR) system of maximum lag order}

For the Johansen's cointegration tests the relevant order of lag of VAR model should be specified. For this purpose, the study used AIC, BIC and HQC. Table 5 shows that the results of the optimal lag selection. It suggests at least five lags. The information below indicates the best (that is, minimized) values of the respective information criteria. 
Table 5: Vector Autoregression system of lag order

\begin{tabular}{|l|l|l|l|l|l|}
\hline Lags & Loglik & $\mathrm{p}(\mathrm{LR})$ & AIC & BIC & HQC \\
\hline 1 & 2.24518 & & 0.959137 & 1.282408 & 0.839451 \\
\hline 2 & 11.59705 & 0.00002 & -0.432842 & -0.069162 & -0.567489 \\
\hline 3 & 25.03530 & 0.00000 & -2.505883 & -2.101794 & -2.655491 \\
\hline 4 & 28.93831 & 0.00521 & -2.989719 & -2.545221 & -3.154288 \\
\hline 5 & 365.26336 & 0.00000 & $-58.877227^{*}$ & $-58.392320^{*}$ & $-59.056756^{*}$ \\
\hline
\end{tabular}

Notes: * indicates lag order selected by the standard

$\mathrm{AIC}=$ Akaike criterion, $\mathrm{BIC}=$ Schwarz Bayesian criterion and HQC $=$ Hannan-Quinn measure.

\subsubsection{Johansen Test for Cointegration}

This study has used a model to examine long run relationships between macro variables and the stock market. For this purpose cointegration analysis is considered to be an ideal tool. So it uses the Johansen (1991) procedure. For the VECM this study first determine the order of integration of the variables.

\section{Table 6: Johansen Test for Cointegration}

\begin{tabular}{|l|l|l|l|l|l|}
\hline Rank & Eigenvalue & Trace Test & P-Value & $\lambda$ max Test & P-Value \\
\hline 0 & 0.96582 & 171.33 & 0.0000 & 54.019 & 0.0038 \\
\hline 1 & 0.90280 & 117.32 & 0.0006 & 37.295 & 0.0985 \\
\hline 2 & 0.86080 & 80.020 & 0.0053 & 31.550 & 0.0908 \\
\hline 3 & 0.74659 & 48.470 & 0.0420 & 21.964 & 0.2292 \\
\hline 4 & 0.59115 & 26.506 & 0.1172 & 14.310 & 0.3537 \\
\hline 5 & 0.40959 & 12.196 & 0.1490 & 8.4309 & 0.3444 \\
\hline 7 & 0.20968 & 3.7651 & 0.0523 & 3.7651 & 0.0523 \\
\hline
\end{tabular}

Notes: This table displays the time series cointegration tests using the Johansen's method for the sample period Mid-July 1994 to Mid-July 2015 Significant at the 5-percent level.

The two Johansen tests for cointegration namely Eigenvalue Test and Trace statistics, have been used to establish the rank of $\beta$. In other words, how many cointegration vectors the system has can be ascertained by the Johansen tests for cointegration.

The above table shows that the trace and $\lambda$ max tests reject the null hypothesis that the smallest eigenvalue is not 0 , thus it concludes that the series are in fact stationary. However, the study considered only the cointegrating vector represented by largest eigenvalue (stock prices). The cointegrating vector 
normalized on the stock prices (with the largest eigenvalue) is given by $\beta 1=$ $(1.000,121.71,-25.208,-1.8152,-15.835,1.4989$, and -36.529).

These cointegrating vectors represent the long-run equilibrium relationship among the variables and values are the coefficients of LNEPSE (normalized to one), LGDP, LEXR, LFDI, LM1, LTBR and LCPI a linear trend, and are long term elasticity measures due to logarithmic transformation. The above vector can be explained as:

LNEPSE $=-121.71 \mathrm{LGDP}+25.208 \mathrm{LEXR}+1.8152 \mathrm{LFDI}+15.835 \mathrm{LM} 1-1.4989 \mathrm{LTBR}+36.529 \mathrm{LCPI}$

$(4.7183)^{* * *} \quad(-1.4119) \quad(1.0025) \quad(0.4963) \quad(1.7685) * \quad(1.3073) \quad(0.3466)$

*Significant at the 5-percent level,

***Significant at the 10-percent level

The above estimated cointegration relationship of equation shows that real economic activity has insignificant and negative relationship with the stock prices. It is inconsistent to the results provided by Fama (1981); Chen, Ross and Roll (1986), Kaul (1987); Lee (1992); Ratnapakorn and Sharma (1997) in the US, by Mukherjee and Naka (1995) in Japan, by Naka, Mukherjee and Tufte, (1999) in India and by Joshi (2008) in Nepal. So, there is no direct relationship between them.

The result of this study also implies that a positive and insignificant relationship between exchange rate and the Nepalese stock market. This is consistent to findings of Mukherjee and Naka (1995) for Japan; Maysami, Howe, and Hamzah (2004) for Singapore; Phylaktis and Ravazzolo (2005) for Pacific Basin countries (Hong Kong, Malaysia, Singapore, Thailand and the Philippines); Ratnapakorn and Sharma (2007) for US and Joshi (2008) for Nepal.

Similarly, foreign direct investment and stock returns have a positive and insignificant relationship means if FDI increases then it leads to industrial growth and thereby increases stock prices. Tarzi (2005) investigates the flow of both foreign portfolio equity investments (FPEI) and foreign direct investment (FDI) to rising markets. Between 1986 and 1995 stock market capitalization in emerging countries grew ten-fold from $\$ 171$ billion to 1.9 trillion and market share held in capitalization increased from 4 percent to 11 percent, mostly to the nine major upand-coming markets together with Brazil, India, and Hong Kong (now a province of China).

There is evidence that stock prices are positively and significantly related to money supply. This finding is similar to positive relationship examined by Shrestha and Subedi (2014) for Nepal; Mukherjee and Naka (1995) for Japan; Naka, Mukherjee and Tufte (1999) for India; Mayasami, Howe and Hamzah 
(2004) for Singapore, Ratnapakorn and Sharma (2007) for US. This finding implies that monetary policy in Nepal has positive impact on stock prices, since central bank in Nepal uses the credit control (Control money supply) as an intermediate targets in monetary policy framework. The positive relationship may be because increase in money supply increases cash in hand and growth, ultimately earnings and dividends and thereby increasing stock prices.

Interest rate has negative and insignificant relationship with stock prices. The negative relationship is similar to our hypothesis and is consistent with the present value model. This is however consistent to the findings of Shrestha and Subedi (2014) for Nepal; Mukherjee and Naka (1995) for Japan and Ratnapakorn and Sharma (2007) for USA who argue that short term interest rate are positively related to stock prices (at Short-Term Analysis and Granger Causality). One of the reasons may be increasing in interest rate decreases the lending rate. With the high interest rate spread individuals will expect decrease investment in future, which ultimately decreases profit of banking and financial institution which has predominance in the Nepalese stock market thus decreasing the stock price.

Finally inflation (CPI) has insignificant influence over the stock prices in the cointegrating vector against the hypothesis of relationship. Humpe and Macmillan (2007) also find similar result for Japan and Joshi (2008) in Nepal. However, this result is consistent to Fisher's model which expect a positive relationship and the empirical findings in Chen, Ross and Roll (1986); Lee (1992), Canada (Darrat, 1990), Japan (Mukherjee and Naka, 1995), India (Naka, Mukherjee and Tufte, 1999). One reason for such existence may be because Nepalese inflation is driven by Indian inflation rather those other domestic factors such as real economic activity or money supply in the long run.

\subsubsection{Short-Term Analysis and Granger Causality}

As the Granger explaination, when given variables are cointegrated, then error correction model (ECM) help to explain the short-run dynamics or adjustments of the cointegrated variables towards their equilibrium values along with oneperiod lagged cointegrating equation and the lagged first differences of the endogenous variables. This also provides the causal relationship among the stock prices and the macroeconomic variables which can be determined by estimating VEC model of equation. Equation presented as below explains the empirical estimates from the VEC model for stock price equation only.

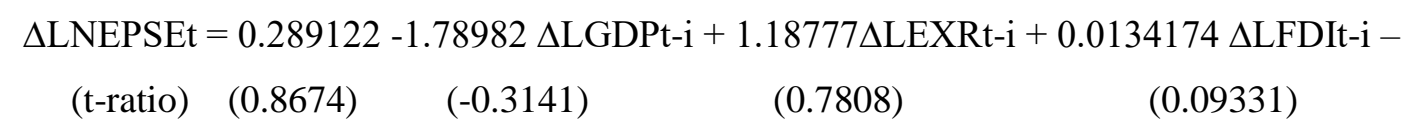

$0.496141 \Delta$ LM1t-i $+0.267571 \Delta$ LTBRt-I -1.91727 LCPIt-I
$(-0.2407)$
(1.127)
$(-0.4843)$ 
The VEC estimates show that one-period lagged error correction term is statistically significant at 5 percent level but positive. The constant term is 0.289122 which suggests a slow speed of adjustment back to the long run equilibrium. Moreover, this indicates that about 28 percent of disequilibrium exerted by a short run shock is corrected each year following the shock. At this rate, it takes around three years to come back to the long run equilibrium. The estimates suggest that there is no significant effect of macroeconomic variables to the Nepalese stock prices. The estimates also suggest that immediate past changes in inflation, money supply and gross domestic activity negatively affect stock returns while exchange rate, foreign direct investment and interest rate have positive impact on stock returns.

\section{CONCLUSION}

This study examines the interaction of share returns and the macroeconomic variables as a subject of interest among academics, investor and practitioners. It is found that stock prices are determined by some fundamental macroeconomic variables such as the interest rate, the exchange rate and the money supply. Similarly, the financial pressure indicates that the investors generally believe that monetary policy and the macroeconomic events have a large influence on the volatility of the stock price. This implies that macroeconomic variables can influence investors' investment decision and motivates as a previous study of the relationships between share returns and macroeconomic variables of many researchers. Similarly, there is no data significant except money supply in the long run analysis while no significant in the short run analysis. But overall, the presence of cointegration and causality suggests that Nepalese stock market is not efficient in both the short run and the long run. It causes that, it is driven by economic fundamentals and hence publicly available information on macroeconomic variables can be potentially used in predicting stock prices.

\section{REFERENCES}

Al-Khazali, O.M. 2003. "Stock Prices, Inflation, and Output: Evidence from Emerging Markets." Journal of Emerging Finance, 2: 287-314.

Allen, D., Lim, L.K., and T. Winduss. 2004. "The Present Value of Pacific Basin Stock Markets: A Domestic and External Factor Model." Working Paper, Retrieved from www.ssrn.com.

Arnold, I. J.M. and E. B. Vrugt. 2006. "Stock Market Volatility and Macroeconomic Uncertainty Evidence from Survey Data." NRG Working Paper no. 06-08. Retrieved from http://www.nyenrode.nl/research/publications. 
Chen, N., Roll, R. and S. A. Ross. 1986. "Economic Forces and the Stock Market." Journal of Business, Vol.59, No3, pp383-403.

Crowder, W.J. 2006. "The Interaction of Monetary Policy and Stock Returns." The Journal of Financial Research, 39(4):523-35.

Darrat, A.F., and R.N. Dickens. 1999. "On the Interrelationship among Real, Monetary, and Financial Variables.” Applied Financial Economics, 9 :289-293.

Dickey, D.A. and W.A. Fuller. 1981. "Likelihood Ratio Statistics for Autoregressive Time Series with a Unit Root." Econometrica, 49(4):1057-72.

Dickey, D.A. and W.A. Fuller. 1979. "Distribution of the Estimators for Autoregressive Time Series with a Unit Root." Journal of the American Statistical Association. 74, (366): 427-31.

Engle, R.F. and C.W.J. Granger. 1987. "Co-Integration and Error Correction: Representation, Estimation and Testing." Econometrica, 55 (2):251-76.

Fama, E. F. 1981. "Stock Returns, Real Activity, Inflation and Money." American Economic Review, 71(4): 545-65.

Fama, E.F. 1970. "Efficient Capital Markets: A Review of Theory and Empirical Work." The Journal of Finance, 25(2): 383-417.

Flannery, M.J. and A.A. Protopadakis. 2002. "Macroeconomic Factors do Influence Aggregate Stock Returns.” The Review of Financial Studies, 15:751-81.

Gan, C., Minsoo, L., Hua Hwa A. Y. and Z. Jun. 2006. "Macroeconomic Variables and Stock Market Interactions: New Zealand Evidence." Investment Management and Financial Innovations, Volume 3, Issue 4, 2006.

Gay, R. D. 2008. "Effect of Macroeconomic Variables on Stock Market Returns for Four Emerging Economies: Brazil, Russia, India and China." International Business \& Economic Research Journal -Volume 7, Number 3, Jr., Nova Southeastern University. Retrieved from www.ssrn.com.

Gujarati, D. 2003. Econometrics, Singapore: McGraw-Hill.

Gretl 4.4. 2011. Software. Retrieved from http://gretl.sourceforge.net

Gunasekarge, A., Pisedtalasai, A., and M. Power. 2004. "Macroeconomic Influence on the Stock Market: Evidence from and Emerging Market in South Asia." Journal of Emerging Finance, 3: 285-304.

Humpe, A. and P. Macmillan. 2007. "Can Macroeconomic Variables Explain Long Term Stock Market Movements?: A comparison of the US and Japan.” Retrieved from www.ssrn.com.

Johansen, S. 1991. "Estimation and Hypothesis Testing of Cointegration Vectors in Gaussian Vector Autoregressive Models", Econometrica, Vol. 59,(6):1551-80. 
Johansen, S., and K. Juselius. 1990. "Maximum Likelihood Estimation and Inferences on Cointegration with Applications to the Demand for Money." Oxford Bulletin of Economics and Statistics, 52: 169-210.

Joshi, N. K. 2009. "Macroeconomic Factors and Stock Market: Evidence from Nepal." Unpublished M. Phil. Thesis, CEDECON, TU Nepal.

Joshi, N. K. 2008. "Dynamic Relationship among the Stock Market and the Macroeconomic Factors: Preliminary Evidence from Nepalese Stock Market." Journal of Economics, Patan M. Campus, TU.

Laopodis, N.T. 2006. "Dynamic Interactions among the Stock Market, Federal Funds Rate, Inflation and Economic Activity." The Financial Review, 41:513-45.

Lee, B.S. 1992. "Causal Relations among Stock Returns, Interest Rates, Real Activity and Inflation." The Journal of Finance, 47(4):1591-1603.

Lee, U. 1997. "Stock Market and Macroeconomic Policies: New Evidence from Pacific Basin Countries." Multinational Finance Journal, 1(4): 273-89.

Maysami, R.C., Howe, L.C., and M.A. Hamzah. 2004. "Relationship between Macroeconomic Variables and Stock Market Indices: Cointegration Evidence from Stock Exchange of Singapore's All-S Sector Indices." Jurnal Pengurusan, 24: 47-77.

Mookerjee, R. and Q. Yu. 1997. "Macroeconomic Variables and Stock Prices in a Small Open Economy." Pacific-Basin Finance Journal, 5: 377-88.

Mukherjee, T. and A. Naka. 1995. "Dynamic Linkage between Macroeconomic Variables and the Japanese Stock Market: An Application of a Vector Error Correction Model." Journal of Financial Research, 18: 223-237.

Naka, A., T. Mukherjee, and D. Tufte. 1999. "Macroeconomic Variables and the Performance of the Indian Stock Market." Working Paper. Retrieved from www.ssrn.com.

Nepal Rastra Bank. 2017. Quarterly Economic Bulletin, Volume 51, Number 4, Nepal Rastra Bank, Kathmandu.

Park, K. and and R.A. Ratti. 2000. "Real Activity, Inflation, Stock Returns, and Monetary Policy." The Financial Review, 35 (2): 59-77.

Patra, T., and S. Poshakwale. 2006. "Economic Variables and Stock Market Returns: Evidence from the Athens Stock Exchange." Applied Financial Economics, 16:993-1005.

Pilinkus, D. 2009. "Stock Market and Macroeconomic Variables: Evidences from Lithuania." Economics and Management: 2009.14, ISSN 1822-6515. Kaunas University of Technology, Lithuania, pilinkus@ pilinkus.com 
Phylaktis, K. and P. Ravazzolo. 2005. "Stock Prices and Stock Exchange Rate Dynamics." Working Paper. Retrieved from www.ssrn.com.

Ratanapakorn, O., and S.C. Sharma. 2007. "Dynamic Analysis between the US Stock Returns and the Macroeconomic Variables." Applied Financial Economics, 17:369-377.

SEBO. 2007 \& 2011. Annual Report. Securities Board, Nepal.

Shrestha, P. K. and B. R. Subedi. 2014. "Determinants of Stock Market Performance in Nepal." NRB Economic Review, 26-2: 25-40.

Tarzi, S. 2005. "Foreign Direct Investment Flows into Developing Countries: Impact of Location and Government Policy." The Journal of Social, Political, and Economic Studies, 30, 4, 497-515.

Tsoukalas, D. 2003. "Macroeconomic Factors and Stock Prices in the Emerging Cypriot Equity Market." Managerial Finance, 29 (4): 87-92.

Tursoy, T., Nil G. and R. Husam. 2008. "Macroeconomic Factors, the APT and the Istanbul Stock Market." International Research Journal of Finance and Economics Issue, 22. Retrieved from http://www.eurojournals.com/finance.htm.

Wickremasinghe, G.B. 2006. "Macroeconomic Forces and Stock Prices: Some Empirical Evidence from an Emerging Market." Working Paper, University of Wollongong. Retrieved from www.ssrn.com. 